\title{
The Effect of Entrepreneurial Marketing on Competitive Advantage: Small Culinary Souvenir Industry in Jalan Mojopahit Medan, Indonesia
}

\author{
Nico Makmur \\ Department of Management \\ University of Sumatra Utara \\ Medan Indonesia \\ Inneke Qamariah \\ Department of Management \\ University of Sumatera Utara \\ Medan, Indonesia
}

\author{
Yasmin Chairunisa \\ Department of Management \\ University of Sumatera Utara \\ Medan, Indonesia \\ Fadli \\ Department of Management \\ University of Sumatera Utara \\ Medan, Indonesia
}

\begin{abstract}
This study aims to investigate the effect of entrepreneurial marketing dimensions namely: pro-activeness; calculated risk-taking; innovativeness; opportunity focus; resource leveraging; customer intensity and value creation on competitive advantage in small Medan culinary souvenir industry in Jalan Mojopahit Medan, Indonesia. This study uses thirty-four samples. Data analysis used in this study is multiple linear regression. This multiple regression analysis indicates that entrepreneurial marketing has significant and positive effects on competitive advantage
\end{abstract}

Keywords - Entrepreneurial Marketing, Dimensions of Entrepreneurial Marketing, Competitive Advantage, Multiple Regression

\section{INTRODUCTION}

According to the Ministry of Industry of the Republic of Indonesia, the contribution of micro, small and medium enterprises to gross domestic product (GDP) is 60.3 percent. This sector also contributes to the employment of 97.22 percent. The SME sector plays an important role in improving the economic growth of Indonesia. Therefore, SMEs should be further developed to improve the Indonesian economy. One of the most important elements in the development of SMEs is marketing. Marketing plays a significant role in large organizations, but it cannot be denied that marketing is more crucial in small and medium enterprises due to the loss or increase of one consumer will greatly determine the viability of the business [1]. But marketing theory in big companies cannot be totally implemented in SMEs [2]. That is why to win the competition with existing competitors in the marketplace, business owners are required to see opportunities better and use available resources and expertise to enhance and innovatively create value in the marketing process [3]. The business owner must consider market uncertainty as common and try to take advantage of the opportunities created by the changes [4].
Entrepreneurial marketing (EM) is a concept created from two sciences: marketing and entrepreneurship [5]. Entrepreneurial marketing is a science developed to explain the part of marketing that cannot be explained by existing traditional marketing concepts and theories [6]. Entrepreneurial marketing is based on the needs and development of marketing management competence and try to innovate in parts that can still be developed. Therefore, entrepreneurship deals with marketing and marketing related to entrepreneurship [3]. With entrepreneurial marketing, the entrepreneurial marketing mix is easier and more complicated than conventional marketing which uses traditional marketing techniques [7]. If an entrepreneur can apply entrepreneurial marketing in its marketing activities, the opportunities for achieving competitive advantage will be greater. Therefore, entrepreneurial marketing is important to be learned by small and medium business owners if they want to grow big in the business that they are working on.

This study aims to investigate the effect of entrepreneurial marketing (pro-activeness; calculated risk-taking; innovativeness; opportunity focus; resource leveraging; customer intensity and value creation) simultaneously and partially on competitive advantage in small culinary souvenir industry in Jalan Mojopahit Medan, Indonesia.

\section{LITERATURE REVIEW AND HYPOTHESIS}

\section{A. Entrepreneurial Marketing}

The limitations of small and medium-sized businesses in marketing create a theory that combines marketing with entrepreneurship. Entrepreneurial marketing is a term often associated with marketing activities in a small business which has limited resources and must rely on creative and elementary marketing tactics utilizing personal social networks [8]. Implementation of entrepreneurial marketing can generate more value for customers and organizations. Entrepreneurial marketing also explains how decision makers can use limited 
resources to optimally solve problems [9]. Innovation is the implementation of the idea in practice.

Entrepreneurial marketing is the result of entrepreneurial interpretation of information, decision-making and marketing action. Entrepreneurial marketing is a passion and orientation as well as a process for pursuing opportunities, creating and developing value-creating efforts for customers through relationships by applying innovation, creativity, sales, marketing, networking and flexibility [10]. It is a fact that entrepreneurial marketing is on a different level of understanding and complexity of traditional marketing concepts.

Table 1. Consept

\begin{tabular}{|c|c|c|}
\hline & Traditional Marketing & Entrepreneurial Marketing \\
\hline Foundation & $\begin{array}{l}\text { To facilitate transaction } \\
\text { and control market. }\end{array}$ & $\begin{array}{l}\text { Competitive advantage } \\
\text { through value adding } \\
\text { innovation. }\end{array}$ \\
\hline Orientation & $\begin{array}{l}\text { Marketing is an } \\
\text { objective and does not } \\
\text { related to passion. }\end{array}$ & $\begin{array}{l}\text { Passion and creativity are } \\
\text { important in marketing. }\end{array}$ \\
\hline Context & $\begin{array}{l}\text { Organized, stable } \\
\text { market. }\end{array}$ & Prediction, market is volatile. \\
\hline Marketeer role & $\begin{array}{l}\text { Coordinate marketing } \\
\text { mix and building brand. }\end{array}$ & $\begin{array}{l}\text { Create changes internally } \\
\text { and externally and develop } \\
\text { category. }\end{array}$ \\
\hline Market approach & $\begin{array}{l}\text { Adapting with less } \\
\text { innovation. }\end{array}$ & $\begin{array}{l}\text { Proactive approach with } \\
\text { innovation and creativity. }\end{array}$ \\
\hline Customer need & From survey & From customer \\
\hline Risk Perspective & $\begin{array}{l}\text { Minimize risk in } \\
\text { marketing operation. }\end{array}$ & Marketing to mediate risk. \\
\hline $\begin{array}{l}\text { Resource } \\
\text { Management }\end{array}$ & $\begin{array}{l}\text { Limited to utilizing } \\
\text { available resources. }\end{array}$ & $\begin{array}{l}\text { Not limited to available } \\
\text { resources, but add value to } \\
\text { the available limited } \\
\text { resources. }\end{array}$ \\
\hline $\begin{array}{l}\text { Product } \\
\text { Development }\end{array}$ & $\begin{array}{l}\text { Marketing supports new } \\
\text { product development. }\end{array}$ & $\begin{array}{l}\text { Innovation comes from } \\
\text { marketing activity and } \\
\text { customers. }\end{array}$ \\
\hline Customer's role & $\begin{array}{l}\text { Source of external ideas } \\
\text { and evaluations. }\end{array}$ & $\begin{array}{l}\text { Active elements in decision } \\
\text { making, pricing, distribution } \\
\text { and communication. }\end{array}$ \\
\hline
\end{tabular}

\section{Pro-activeness}

Proactive can be interpreted as taking action or initiative to do something to achieve the intended purpose [11]. A proactive person is more likely to take responsibility for creating a creative change and effort when equipped with abilities and supports [12]. Pro-active orientation as marketers defines external conditions to reduce uncertainty and reduce dependence and vulnerability. Proactively reflects the willingness of an entrepreneur to dominate a competitor with a combination of proactive and aggressive attitudes [13].

\section{Opportunity Focus}

Opportunity is an unidentified market position that holds a sustainable profit potential [8]. The biggest challenge of an SME is to identify and seize the opportunities [13]. Business performance rests on business opportunities resulting from an emerging activity. Opportunities are a source of sustainable profit potential [7] thus, the ability to determine and pursue existing opportunities is a core ability in determining the success of an SME [14]. Although the idea and creativity of the business owner is essential in business, the idea and creativity will be useless if not supported by the ability to identify opportunities that exist in the market [15]. From the results of the research of Refrence [16], entrepreneurial experience, market sensitivity, and knowledge positively influence the identification of opportunities for an entrepreneur.

\section{Customer Intensity}

This dimension is based on a customer-centered orientation by using innovation to create, build and maintain customer relationships [14]. The number of customers has an essential role in the survival of small and medium enterprises due to the loss or increase of one consumer will greatly determine the survival of the business [1].

Satisfied customers will benefit businesses in the short and long term because customer satisfaction is closely related to customer loyalty, trust and emotional components in the relationship between customers and businesses [17]. Other research indicates that not only optimal service has an effect on customer satisfaction, but product quality and production performance of a company is also not less important with optimal service given to the customer [18].

\section{Innovation}

Innovation is the process of creating something new [19] and combining existing resources in new and more productive ways [4]. Innovations range from the creation of new products that can transform the industry up to the development of waste disposal methods in the production process [20]. Innovation is the core of the entrepreneurial process [19].

According to reference [21] innovation has three dimensions: product, process, and market. To enhance the ability of innovation, SMEs can also develop an entrepreneurial orientation strategy because entrepreneurial orientation positively affects the ability of innovation [22]. 


\section{Risk-Taking}

Although opportunity brings the possibility to make profit, in pursuit of the profit, the calculation of possible losses must be done [1]. Reference [23] stated that there are seven factors to improve the effectiveness of risk management in risk-taking procedures: commitment and support from top management, communication, culture, information, organizational culture, training, and trust.

But not every business takes a risky step. An effort that feels in a superior position in the competition prefers to make safe decisions and avoid risky decision-making. Conversely, businesses that feel less superior in the market competition are more likely to take more risky decisions to compete with existing competitors in the market [24].

\section{Resource Leveraging}

The most essential resource for a company is the human resource who contribute his work, talent, creativity and morale for a greater purpose [7]. To win the competition in the market, SME owners not only focus on product diversification, but also resource diversification can also help SMEs to excel in competition by increasing the production capability. This way, SME owners can maximize production effectiveness and efficiency [25].

If the efficiency and effectiveness of production have reached its peak, SME owners can start selecting production factors that have the following criteria: valuable, rare and nonreplicable. Sustainable competitive advantage can be achieved if one utilize the resources mindfully [26].

\section{Value Creation}

Entrepreneurial marketing is a package of processes for creating, communicating and delivering value to customers [5]. The focal point of Entrepreneurial Marketing is the creation of innovative value, on the assumption that value creation is a requirement for transactions and relationships [7]. Value creation does not occur in a single transaction. It is created in the long term with the support of the ability of SMEs in providing peace of mind in consuming the product, certainty, and clarity of the product and no worries in consuming the products offered to the customers [27]. Value is created through improvisation, and there are many ways to do it. Consciously trying to reinforce existing values and create new values is one way but requires a lot of information as value is not a universal necessity".

\section{B. Competitive Advantage}

Competitive advantage is the heart of corporate performance in competitive markets [28]. Competitive advantage shows that a business has better business performance than competitors who are in the same industry using its assets and competencies [4]. Sustainable competitive advantage is the result of implementing value creation strategies that are not periodically incorporated by competitors, and other businesses cannot duplicate the benefits of the method used [29].

There are two dimensions of competing advantages according to reference [30]
1. Cost advantages: The price is lower than competitors.

2. Differentiation advantages: Different products from competitors ranging from product delivery to product usage.

\section{Micro, Small and Medium Enterprise}

In accordance with Undang-Undang Nomor 20 Tahun 2008 in Indonesia regarding Micro, Small and Medium Enterprises (MSMEs), the definition of MSME is as follows:

1. Micro enterprise is productive business owned by individual and / or individual business entity fulfilling the criteria:

a. Having a net worth of at most Rp50.000.000 (fifty million rupiah) excludes land and building of business premises.

b. Has annual sales of at most Rp300.000.000 (three hundred million rupiah).

2. Small enterprise is a stand-alone productive economic enterprise, carried out by an individual or a business entity which is not a subsidiary or not a branch of a company owned, controlled or constituted either directly or indirectly by a medium or large-scale business that meets the criteria :

a. Having a net worth of more than Rp50.000.000 (fifty million rupiah) up to a maximum of Rp500.000.000 (five hundred million rupiah) excluding land and building of business premises.

b. Has annual sales of more than Rp300.000.000 (three hundred million rupiah) up to a maximum of Rp2.500.000.000 (two billion five hundred million rupiah).

3. Medium-sized enterprises are stand-alone productive economic enterprises, carried out by individuals or business entities that are not subsidiaries or branches of a company owned, controlled or become part directly or indirectly with Small Business or Large Business with net worth amount or annual sales results that meet the criteria:

a. Having net worth of more than Rp500.000.000 (five hundred million rupiah) up to a maximum of Rp10.000.000.000 (ten billion rupiah) excluding land and building of business premises.

b. Has annual sales of more than Rp2.500.000.000 (two billion five hundred million rupiahs) up to a maximum of Rp50.000.000.000 (fifty billion rupiahs).

\section{Hypothesis}

Based on the description above, the hypothesis can be stated as follows:

H1: Entrepreneurial marketing positively affects competitive advantage. 
H2: Opportunity Focus positively affects competitive advantage.

H3: Pro-activeness positively affects competitive advantage.

H4: Customer Intensity positively affects competitive advantage.

H5: Risk-taking positively affects competitive advantage.

H6: Resource Leveraging positively affects competitive advantage.

H7: Value Creation positively affects competitive advantage.

H8: Innovation positively affects competitive advantage

\section{METHODOLOGY}

\section{A. Sample and Data Collection}

The population of this study is 34 small culinary souvenir industry in Jalan Mojopahit Medan, Indonesia. This study implement saturated sampling technique. That means all 34 small culinary souvenir industry in Jalan Mojopahit Medan, Indonesia are used as the sample.

\section{B. Measures}

All construct are measured using five-point Likert scales ranging from $1=$ strongly disagree to $5=$ strongly agree. This scale consists of 7 dimensions, namely pro-activeness (8 items), calculated risk-taking ( 8 items), innovativeness (8 items), opportunity focus (8 items), resource leveraging (9 items), customer intensity ( 9 items) and value creation (6 items). This research is using five-point Likert Scales ranging $1=$ strongly disagree to $5=$ strongly agree to measure competitive advantage.

In this study, questionnaire for performance appraisal using a subjective scale, that is the perception of the manager or owner of the industry

\section{Analysis and Results}

The results of the instrument's validity and reliability test of all the variables shows that it is valid and reliable.

\section{Table 2}

Regression analysis result for entrepreneurial marketing and competitive advantage

\begin{tabular}{|c|c|c|c|c|c|c|}
\hline \multirow{2}{*}{\multicolumn{2}{|c|}{ Model }} & \multicolumn{2}{|c|}{$\begin{array}{l}\text { Unstandardized } \\
\text { Coefficients }\end{array}$} & \multirow{3}{*}{$\begin{array}{l}\text { Standardized } \\
\text { Coefficients } \\
\text { Beta }\end{array}$} & \multirow{3}{*}{$\begin{array}{l}\mathrm{t} \\
6.905 \\
\end{array}$} & \multirow{3}{*}{$\begin{array}{l}\text { Sig. } \\
.001 \\
\end{array}$} \\
\hline & & \multirow{2}{*}{$\begin{array}{l}\text { B } \\
12.712 \\
\end{array}$} & \multirow{2}{*}{\begin{tabular}{|l|} 
Std. \\
Error \\
3.255 \\
\end{tabular}} & & & \\
\hline \multirow{8}{*}{1} & (Constant) & & & & & \\
\hline & $\begin{array}{l}\text { Opportunity } \\
\text { focus }\end{array}$ & 1.063 & .284 & .817 & 3.739 & .001 \\
\hline & Pro-activeness & 1.000 & .466 & .862 & 2.148 & .041 \\
\hline & $\begin{array}{l}\text { Customer } \\
\text { Intensity }\end{array}$ & .071 & .083 & .067 & .855 & .401 \\
\hline & Risk Taking & .116 & .063 & .127 & 1.836 & .078 \\
\hline & $\begin{array}{l}\text { Resource } \\
\text { Leveraging } \\
\end{array}$ & .457 & .195 & .318 & 3.344 & .027 \\
\hline & $\begin{array}{l}\text { Value } \\
\text { Creation }\end{array}$ & .755 & .459 & .544 & 1.645 & .112 \\
\hline & Innovation & .216 & .305 & .163 & .708 & .486 \\
\hline
\end{tabular}

$\mathrm{Y}=12.712+1.063 \mathrm{X}_{1}+1.000 \mathrm{X}_{2}+0.071 \mathrm{X}_{3}+0.116 \mathrm{X}_{4}+$ $0.457 \mathrm{X}_{5}-0.755 \mathrm{X}_{6}+0.216 \mathrm{X}_{7}$

$\mathrm{Y}=$ Competitive Advantage

1. Constanta $=12.712$, this means if every variable $\mathrm{X}$ is 0 , then competitive advantage is 12.712 .

2. Coefficient $\beta 1(\mathrm{X} 1)=1.063$, if opportunity focus increases by 1 point, then competitive advantage will increase by 1.063 .

3. Koefisien $\beta 2(\mathrm{X} 2)=1.000$, if pro-activeness increases by 1 point, then competitive advantage will increase by 1.000 .

4. Koefisien $\beta 3(\mathrm{X} 3)=0.071$, if customer intensity increases by 1 point, then competitive advantage will increase by 0.071 .

5. Koefisien $\beta 4(\mathrm{X} 4)=0.116$, if risk-taking increases by 1 point, then competitive advantage will increase by 0.116 .

6. Koefisien $\beta 5(X 5)=0.457$, if resource leveraging increases by 1 point, then competitive advantage will increase by 0.457 .

7. Koefisien $\beta 6(\mathrm{X} 6)=0.755$, if value creation increases by 1 point, then competitive advantage will increase by 0.755 .

8. Koefisien $\beta 7(X 7)=0.216$, if innovation increases by 1 point, then competitive advantage will increase by 0.216 .

\section{Opportunity Focus on Competitive Advantage}

The entrepreneurs always try to find new opportunities to enlarge and improve the business. This can be seen from their answers to the questionnaire where they always pay attention to the changes that occur in the market to identify new opportunities and also develope their products by asking for advice and feedback from customers. Business actors always pay attention to the changes that occur in the market and tries to find opportunities to be utilized. Focus on opportunities is one of the driving factors in achieving sustainable competitive advantage.

\section{Pro-activeness on Competitive Advantage}

Pro-activeness and opportunity focus are two things that cannot be separated to achieve competitive advantage. It has been proven that the business actors are focused on opportunities and it has a significant effect on competitive advantage. But focusing on opportunities will be useless if not accompanied by pro-activeness. Take the initiative to materialize the plan and take steps to materialize the opportunities that have been identified is very important for a business to excel in competing. Business actors there always take the initiative to find the best and consistent way to improve their business.

\section{Customer Intensity on Competitive Advantage}

The concept of Customer Intensity can be interpreted as an adequate understanding of the target customer's purchase with 
the aim of creating a superior value for buyers on a continuous basis through seeking information about customers and services. The differences that occur from this research, Octavia and Morish is the lack of knowledge of business actor about the importance of Customer intensity. Typical business actors focus on quality but do not pay much attention and seek information about their customers. Another reason is because this object of research and Octavia is a business engaged in the product causing customers to receive less attention. Therefore, the results of this study of variables on competitive advantage is not influential.

\section{Risk-taking on Competitive Advantage}

Risk taking almost has a significant effect on competitive advantage but it is not. Business actors on Mojopahit Road are very close together and show very tight competition due to the small and close location. But this study proves that risk does not affect the competitive advantage whereas we know that all business must have risks, especially the way Mojopahit is controlled by Zulaikha shop. From the results of observations by researchers, this happens because the business actors do not expect the sale of ecer in their store. But business actors are distributing their products to distributor outlets in the vicinity of Kuala Namo airport. Therefore, although the market seems to be dominated by Zulaikha, it is not a threat to other businesses. Although occasionally these businesses are at risk for losses if their products do not sell in the distributor at the airport. For this reason the risk-taking in this study shows that the number 0.078 is almost significant.

\section{Resource Leveraging on Competitive Advantage}

SMEs have very minimal resources so that SME owners should be able to use the resources as much as possible. Medan's unique souvenir businessmen on Mojopahit road have used the maximum resources in their business operations starting from the best possible use of raw materials, production efficiency from time, place and cost to recruiting multi-tasking manpower. This can only be done and is very important to do in small-scale enterprises (SMEs) that have very limited resources.

\section{Value Creation on Competitive Advantage}

All business in Jalan Mojopahit is the same that is selling typical souvenir of Medan and its store very close to each other even side by side. Each store creates and assigns the same value to each customer. If there is a store that gives more value, the activity is immediately followed by another store because information about competitors is very transparent and very easy to obtain. Value-giving and value creation are insignificant in this context because customers no longer feel special attention when each store gives the same value. Therefore, value creation in this context is positive but not significant.

\section{Innovation on Competitive Advantage}

Innovation is crucial for the sustainability of SMEs, but in the souvenir of souvenirs whose markets are migrants and tourists, it is not easy to introduce new products. Therefore, SME business actors by on the road Mojopahit not risk to innovate more. The innovation is only a combination of flavors or shapes of products sold. This too can easily be replicated by competitors' efforts because the location is too close together and the information is too transparent. This makes the business actors in Jalan Mojopahit reluctant to innovate because the idea will be very easy to imitate competitors.

As seen in table 1 , the adjusted R2 is 0.913 . That means entrepreneurial marketing explains the $91.3 \%$ of the variance of the competitive advantage. Multiple linear regression test shows that dimensions of Entrepreneurial Marketing significantly influence competitive advantage $(\mathrm{F}=50.262$; sig $=0.000)$. Partial test indicates that the three dimensions of entrepreneurial marketing namely: opportunity focus, proactiveness, and resource leveraging positively and significantly affect competitive advantage. Regression analysis results support $\mathrm{H} 1, \mathrm{H} 2$, and $\mathrm{H} 5$ hypothesis.

\section{CONCLUSION AND LIMITATIONS}

Based on the results of the analysis and discussion done in this study, the conclusions are:

1. Based on the F-test, Entrepreneurial marketing through its variables namely: pro-activeness, opportunity focus, customer intensity, innovation, risk-taking, resource leveraging and value creation simultaneously have a positive and significant impact on competitive advantage in small culinary souvenir industry in Jalan Mojopahit Medan, Indonesia.

2. Based on the T-test, only the variable of opportunity focus, proactiveness, and resource leveraging have a positive effect on competitive advantage. Customer intensity, risk-taking, value creation and innovation variables do not affect the competitive advantage of small culinary souvenir industry in Jalan Mojopahit Medan, Indonesia. The variable of opportunity focus has the most dominant influence on competitive advantage.

3. Based on the calculation of the determinant coefficient (R2) shows that $93.1 \%$ of entrepreneurial marketing variables have a very close influence on competitive advantage

Nevertheless, this study has several weaknesses such as sample and populations are limited to a very small area, and it makes some innovations and actions being easily copied by the competitors. Therefore future researches are suggested to widen the scope of research, perhaps in one city.

\section{References}

[1] Becherer, R. C., Helms, M. M., \& McDonald, J. P. (2012). The Effects of Entrepreneurial Marketing on Outcome Goals in SMEs. New England Journal of Entrepreneurship: Vol.15, No.1, 7-18.

[2] Hamali, S., Suryana, Y., Effendi, N., \& Azis, Y. (2016). Influence of Entrepreneurial Marketing toward Innovation and Its Impact on Business Performance. International Journal of Economics, Commerce and Management: Vol.IV, Issue 8, 101-114.

[3] Gilmore, A. (2011). Entrepreneurial and SME Marketing. Journal of Research in Marketing and Entrepreneurship: Vol.13, No.2, 137-145. 
[4] Jia-sheng, L., \& Chia-Jung, H. (2010). A Research in Relating Entrepreneurship, Marketing Capability,Innovative Capability and Sustained Competitive Advantage. Journal of Business \& Economics Research: Vol 8, No 9, 109-119.

[5] Ionita, D. (2012). Entrepreneurial Marketing : A New Approach for Challenging Times. Management \& Marketing Challanges for the Knowledge Society: Vol.7, No.1, 131-150.

[6] Morrish, S. C., \& Deacon, J. H. (2011). A Tale of Two Spirits: Entrepreneurial Marketing at 42Below Vodka and Penderyn Whisky. Journal of Small Business and Entrepreneurship: Vol.24, No.1, 113-124.

[7] Syah, A. P. (2016). Pengaruh Entrepreneurial Marketing terhadap Kinerja Usaha. Medan: Universitas Sumatera Utara Fakultas Ekonomi dan Bisnis Departemen Manajemen.

[8] Morris, M. H., Schindehutte, M., \& LaForge, R. W. (2002). Entrepreneurial Marketing: A Construct for Integrating Emerging Entrepreneurship and Marketing Perspectives. Journal of Marketing Theory and Practice: Vol.10, No.4, 1-19.

[9] Fillis, I. (2010). The Art of the Entrepreneurial Marketer. Journal of Research in Marketing and Entrepreneurship: Vol.12, No.2, 87-107.

[10] Hills, G. E., \& Hultman, C. M. (2011). Academic Roots: The Past and Present of Entrepreneurial Marketing. Journal of Small Business and Entrepreneurship: Vol.24, No.1, 110-152.

[11] Presbitero, A. (2015). Proactivity in Career Development of Employees : The role of Proactive Personality and Cognitive Complexity. Career Development International: Vol.20, No.5, 525-538.

[12] Jiang, W., \& Gu, Q. (2015). A Moderated Mediation Examination of Proactive Personality on Employee Creativity: A Person-Environment Fit Perspektive. Journal of Organizational Change Management, 393410 .

[13] Short, J. C., Ketchen, D. J., Shook, C. L., \& Ireland, R. D. (2009). The Concept of "Opportunity" in Entrepreneurship Research: Past Accomplishments and Future Challenges. Jpurnal of Management: Vol.36, No.1, 40-67.

[14] Rezvani, M., \& Khazeai, M. (2014). Evaluation of Entrepreneurial Marketing Dimensions According to Characteristics of Institutions: Institutions Age and Size. International Journal of Basic Sciences \& Applied Research: Vol.3, No.4, 207-213.

[15] Heinonen, J., Hytti, U., \& Stenholm, P. (2011). The Role of Creativity in Opportunity Search and Business Idea Creation. Education and Training: Vol.53 (8/9), 659-672.

[16] Li, Y., Wang, P., \& Liang, Y.-J. (2015). Influence of Entrepreneurial Expereince, Alertness and Prior Knowledge on Opportunity Recognition. Social Behavior and Personality: Vol.43, No.9, 1575-1583.
[17] Voigt, K., Lane, S., Severin, K., Turner, D., \& Marcum, C. (2010). The Importance of Successful Customer Service for New and Existing Ventures. Academies International Conference. Academy of Information and Management Sciences: Vol. 14, No.1, 79-83.

[18] Cai, S. (2009). The importance of customer focus for organizational performance: a study of Chinese companies. The International Journal of Quality and Reliability Management: Vol.26, No.4, 369-379.

[19] Barringer, B. R., \& Ireland, R. D. (2010). Entrepreneurship: Successfully Launching New Ventures. New Jersey: Pearson.

[20] Dustin, G., Bharat, M., and Jitendra, M. (2014). Competitive Advantage and Motivating Innovation. Advances in Management: Vol.7, No.1, 1-7.

[21] Ko, H.-T., \& Hsi-Peng, L. (2010). Measuring Innovation Competencies for Integrated Services in the Communications Industry. Journal of Service Management, 162-190.

[22] Wang, Y., \& Panikkos, P. (2010). Entrepreneurial Risk Taking: Empirical Evidence from UK Family Firms. International Journal of Entrepreneurial Behaviour \& Research, 370-38

[23] Abotsi, A. K., Dake, G. Y., \& Agyepong, R. A. (2014). Factors Influencing Risk Management Decision of Small and Medium Scale Enterprises in Ghana. Contemporary Economics: Vol.8, Issue.4, 397414.

[24] Rustambekov, E. (2012). A Stury of Risk-Taking Behaviour in Investment Banking. Michigan: ProQuest .

[25] Andersén, J. (2010). Resource-Based Competitiveness: Managerial Implications of the Resource-Based View. Strategic Direction: Vol.26, No.5, 3-5.

[26] Asad, M. (2014). Porter's Five Forces VS Resource Based View - A Comparison. SSRN Electronic Journal, 1-13.

[27] Cassia, F., Ugolini, M. M., Cobelli, N., \& Gill, L. (2015). Service-Based VS Goods-Based Positioning of the Product Concept: Effects on Customer Perceived Value. TQM Journal: Vol.27, No.2, 247-255.

[28] Prasetya, G. H., Rahardja, E., \& Hidayati, R. (2007). Membangun Keunggulan Kompetitif melalui Aliansi Stratejik untuk Meningkatkan Kinerja Perusahaan (Studi Kasus pada PT. POS Indonesia Wilayah VI Jateng dan DIY) . Jurnal Studi Manajemen dan Organisasi: Vol.4, No.2, $1-19$.

[29] O'Shannassy, T. (2008). Sustainable Competitive Advantage or Temporary Competitive Advantage: Improving Understanding of an Important Strategy Construct. Journal of Strategy and Management: Vol.1, No.2, 168-180.

[30] Porter, Michael. E. (1997). Competitive Strategy. Measuring Business Excellence: Vol 1, Issue 2, 12-17. 